\title{
Kit Device
}

National Cancer Institute

\section{Source}

National Cancer Institute. Kit Device. NCI Thesaurus. Code C50021.

A collection of objects or devices collected tog ether for a particular function or purpose. 